MLM-MU-89-66-0002

\title{
A Study of Microclad Thickness Variation (1987)
}

Ram S. Ramachandran and Kenneth P. Armstrong

June 22, 1989

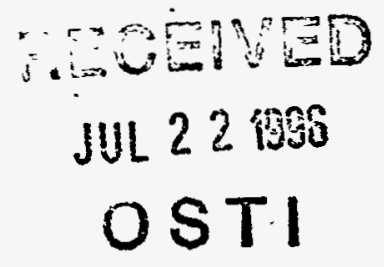

\section{MOUND}

operated by

EG\&G MOUND APPLIED TECHNOLOGIES

P.O. Box 3000, Miamisburg, Ohio 45343-0987

for the

U. S. DEPARTMENT OF ENERGY

Contract No. DE-AC04-88DP43495 


\section{DISCLAIMER}

This report was prepared as an account of work sponsored by an agency of the United States Government. Nelther the Undted States Government nor any agency thereot, nor any of their employets. makes any warranty. express or implled. or assumes any legal llablitty or responslbillty for the accuracy. completeness. or usefulness of any information. apparatus. product. or process disclosed. or represents that its use would not infringe privately owned rights. Reference herein 80 any specific commercial product. process. or service by tracle name. trademark. manufacturer. or otherwise. does not necessarlfy constitute or imply its endorsement. recommendation. or favoring by the United States Government or any agency thereof. The views and opinions of authors expressed herein do not necessarily state or reflect those of the United States Government or any agency thereof. 


\section{A Study of Microclad Thickness Variation (1987)}

Ram S. Ramachandran and Kenneth P. Armstrong

Issued: June 22, 1989

\section{MOUND}

operated by

CSEERE MOUND APPLIED TECHNOLOGIES

P.O. Box 3000, Miamisburg, Ohio $45343-3000$

for the

U. S. DEPARTMENT OF ENERGY

Contract No. DE-AC04-88DP43495 


\section{Contents}

Page

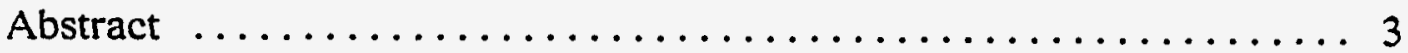

Introduction $\ldots \ldots \ldots \ldots \ldots \ldots \ldots \ldots \ldots \ldots \ldots \ldots \ldots \ldots \ldots \ldots, 3$

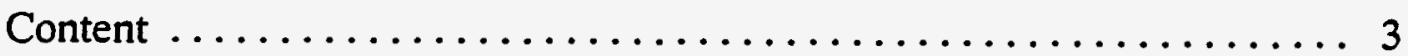

Thickness Variation of Microclad Bridge Material Memo .......... 4

Microclad Raw Material Thickness Study and Disposition of QC\#37826 Memo ............................ 8

Copper Thickness Measurement of Microciad Raw Material by Eddy Current Memo $\ldots \ldots \ldots \ldots \ldots \ldots \ldots \ldots \ldots . \ldots \ldots$

Acknowledgments $\ldots \ldots \ldots \ldots \ldots \ldots \ldots \ldots \ldots \ldots \ldots \ldots . \ldots . \ldots . \ldots$

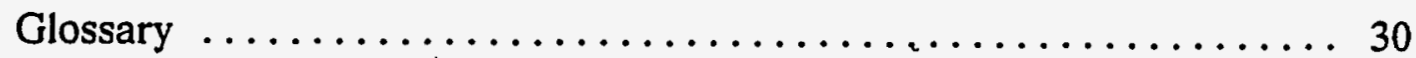

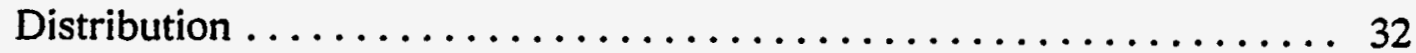




\section{DISCLAIMER}

Portions of this document may be illegible in electronic image products. Images are produced from the best available original document. 


\section{Abstract}

A study was conducted to investigate the thickness variation of microclad material used in fabricating 1E38 bridges. For the role sampled (nine reels), standard deviations within reels ranged from 6.11 to $12.07 \mu \mathrm{in}$. Thickness variations within reels ranged from 16.2 to $40.9 \mu \mathrm{in}$., with the average thickness between 142.90 and $161.28 \mu$ in.

\section{Introduction}

The MC3926 and 1E38 detonators were developed based on studies conducted by Quality, Production, and Development personnel. In the early stages of the programs, the tape process studies were documented in memos. To formally record these studies and make them easily available to interested persons, these memos are being compiled as Mound technical reports. This report documents research performed by R. S. Ramachandran in 1987.

To investigate the thickness variation of microclad (a copper-coated polyimide) used in $1 \mathrm{E}-38$ bridges, a 12 -in. role of $175-\mu$ in. microclad was slit into nine $35-\mathrm{mm}$ reels. Reels 2 through 9 were each $250 \mathrm{ft}$ long, and copper thickness was measured approximately every $5 \mathrm{ft}$. For reel one, which was $30 \mathrm{in.} \mathrm{long,} 75$ readings were taken.

Thickness variations within the reels ranged from 16.2 to $40.9 \mu \mathrm{in}$. The most significant variations were noted in the outermost reels of the roll $(1,2,8$, and 9$)$. The middle five reeis showed acceptable variation. Standard deviations ranged from 6.11 to $12.07 \mu \mathrm{in}$., and the average reel thickness was between 142.90 and $161.28 \mu \mathrm{in}$.

\section{Content}

This report comprises three memos summarizing work performed in the tape process area. The memos are reproduced unedited. 


Date : January 12,1987

Subject : Thickness variätion of microclad bridge material (2 mil)

Reference :

A 12 " roll of 175 microinch microclad material for the 1 E38 bridge (Roll number 1 from QC \#36396) was slit into nine $35 \mathrm{~mm}$ reels. Reels $\frac{\| 2}{\pi}$ thru $\# 9$ were tested for thickness variation by the Eddy Current method (calibrated with PVD materials). Thickness measurements (approx. every 5 feet) were taken along the length of 250 feet of each reel and the summary data are provided in the attached table. Reel \#I which was measured earlier ( 75 readings within 30 inch length) gave an average thickness of 142.9 microinch (lowest) and a standard deviation of 12.07 microinches (highest).

Chart 2 (Standard deviation of thickness measurements on reels by position on the 12-inch roll width of microclad material) exhibits a significant thickness variation within the length of the reel, especially, for the extreme four reels (\#1, \#2, \#8 and \#9). The center five reels (\#3 thru 7) show acceptable deviation along with acceptable average thickness (Chart 1) measurement. It should be noted that Eddy Current method has a bias of an absolute value by about -32 microinches.

I recommend that reels $3,4,5,6$, and 7 which show good consistency in thickness reading be used for the $1 E 38$ Qual 1 lot production. The other four reels should be placed on HOLD for developmental studies.

The current plan is to use the Reel \#2 for correlation studies of thickness measurement capability of Eddy Current vs. Laseruler and vs. Betaback scatter. For this study reel $\# 2$ needs to be etched (1E38 bridge configuration). Please let me know when the reel will be available for the correlation study after completing the wet process on reel $\frac{\|}{\pi} 2$.

Also, when available, please provide me with the individual reel data on the remainder of rolls from this QC Stock (\#36396). Further analysis of data will be - performed to verify the trend of thickness variation within the length of the reel across the width of a microclad roll.

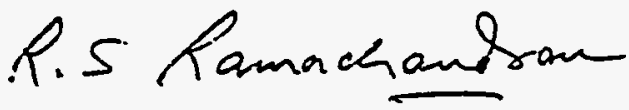

R. S. Ramachandran 
TABLE 1

SUMMARY DATA OF 2 MIL MICROCLAD THICKNESS MEASURED

BY EDDY CURRENT METHOD

\begin{tabular}{|c|c|c|c|c|c|c|}
\hline Reel \#* & $\begin{array}{l}\text { Number of } \\
\text { tests } * *\end{array}$ & $\begin{array}{c}\text { Average } \\
\text { thickness } \\
\end{array}$ & $\begin{array}{l}\text { Std. Dev. } \\
\text { with in the } \\
\text { reel length } \\
\end{array}$ & $\begin{array}{l}\text { High } \\
\text { Value }\end{array}$ & $\begin{array}{c}\text { Low } \\
\text { Value }\end{array}$ & $\begin{array}{c}\text { Thickness Range } \\
\text { within } \\
\text { the reel }\end{array}$ \\
\hline 1 & $75 * \star \star *$ & 142.90 & 12.07 & 150.2 & 134.0 & 16.2 \\
\hline 2 & 50 & 147.94 & 12.06 & 167.5 & 126.6 & 40.9 \\
\hline 3 & 50 & 154.40 & 7.36 & 166.4 & 137.0 & 29.4 \\
\hline 4 & 51 & 160.41 & 6.11 & 169.3 & 144.1 & 25.2 \\
\hline 5 & 35 & 155.96 & 7.05 & 167.6 & 141.4 & 26.2 \\
\hline 6 & 36 & 155.72 & 8.16 & 167.7 & 139.4 & 28.3 \\
\hline 7 & 50 & 157.81 & 7.10 & 172.2 & 139.9 & 32.3 \\
\hline 8 & 50 & 161.28 & 9.77 & 179.5 & 141.3 & 38.2 \\
\hline 9 & 38 & 158.66 & 11.55 & 174.3 & 137.0 & 37.3 \\
\hline
\end{tabular}

* Ro11 \#1 from QC Stock \#36396.

** Thickness measured every five (5) feet (approximately).

*** 75 readings within 30 inch length tape of the reel $\# 1$. 
Chart \# 1

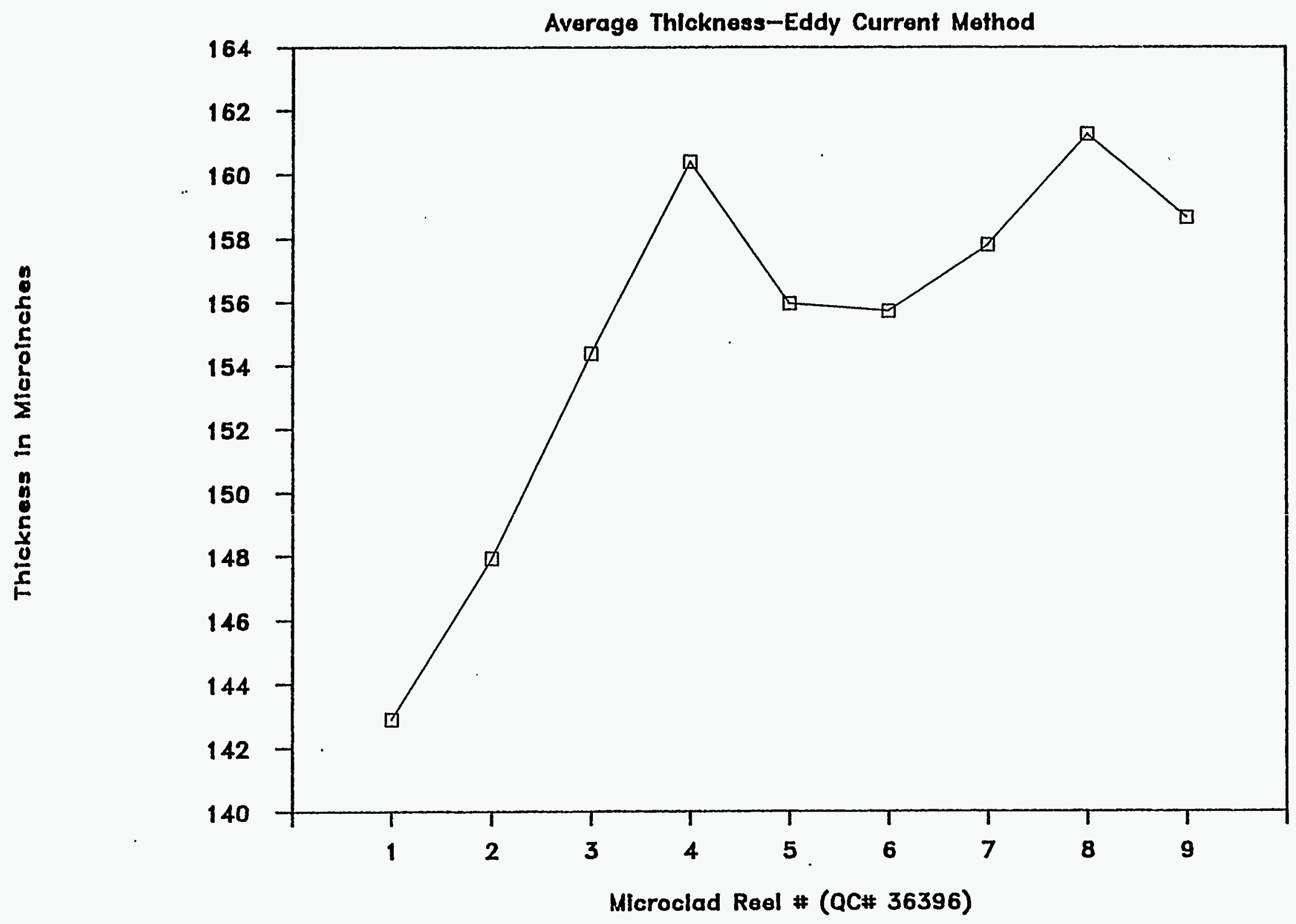


Chart \# 2

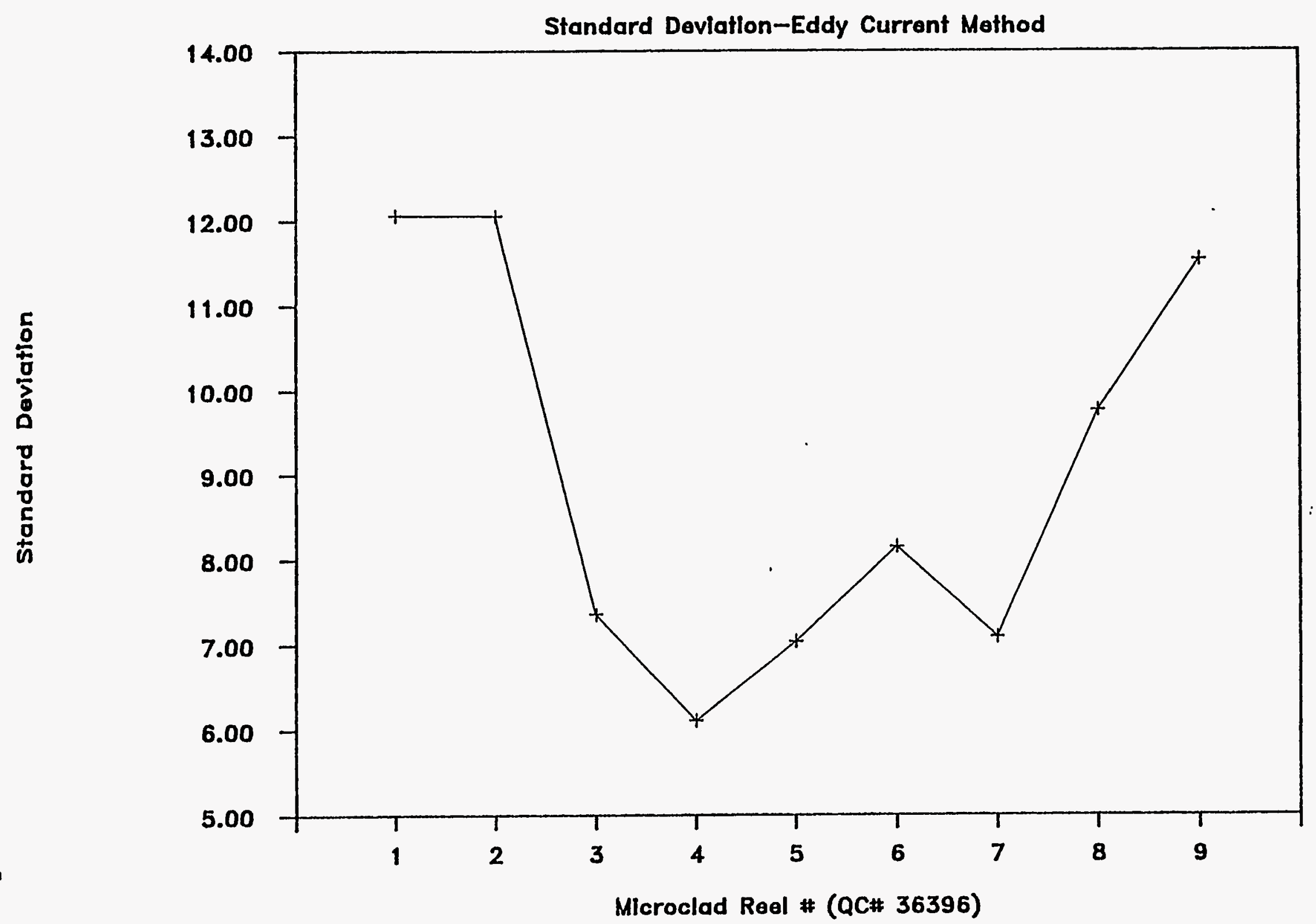




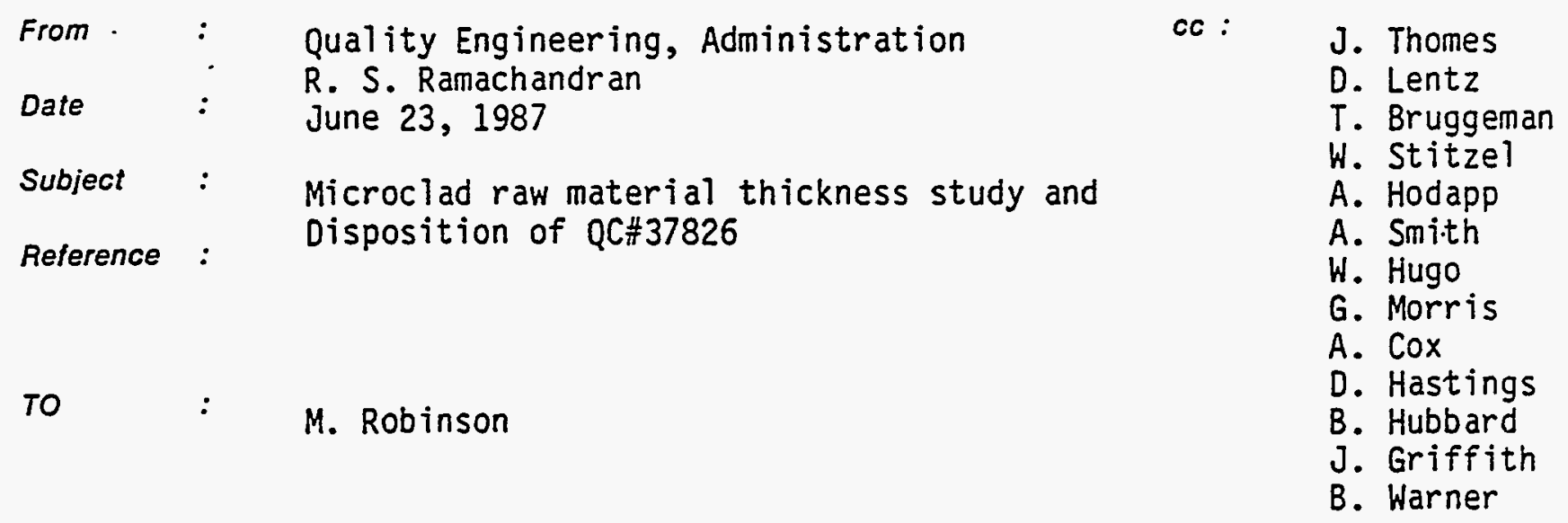

Test Data: Receiving Inspection provided Eddy Current test data of QC\#37826, microclad copper on kapton, 1 E38 raw material. Measurements were made on the eight reels (22-29 from roll \#2) which were sit into $35 \mathrm{~mm}$ from a roll of $12^{\prime \prime}$ width. Each of these reels contained approximately 250 length of material and measurements for copper tinickness were made approximately every five feet.

Conclusion: The microclad copper thickness measurment by Eddy Current showed higher variation between the eight $35 \mathrm{~mm}$ reels (width of the roll) as compared to within the 250 feet length of reel. The same conclusion was obtained with the roll \#1.

Results: Table 1 shows the average copper thickness for eight reels, adjusted for the bias ( -32 microinches) due to the calibration technique using the PVD master standards and the standard deviation within each reel. The copper thickness variation along the 250 feet length is about 2.51 microinches (pooled standard deviation within the reels) with an overall average thickness of 172.3 microinches, excluding the outliers $(n=326)$. The standard deviation between reels across the width of the roll was calculated to be 12.97 microinches.

Observations: Chart 1 provides a perspective view of response surface of the 359 data points across the width and length of the roll $\# 2$. Chart 2 shows the frequency distribution with all the data points $(n=359)$ indicating some skewness and the Chart 3 shows the frequency plot deleting the data points after the $43 \mathrm{rd}$ $(n=326)$ measurement along the length of each roll.

Plot 1 shows graphically the average copper thickness measurements by reel and the standard deviation within the reel for the eight reels, considering all the data points. Plot 2 shows average copper thickness across the width for each successive reading along the length of the reel for 43 data points and plot 3 is the standrd deviation between reels at each successive points across the width.

Disposition: Based on plot $1,6,7,8$, and 11 , reels $4,5,6$, and 9 show a good consistency in thickness measurements with an acceptable average. These reels are acceptable for $1 E 38$ Qual 2 production. It is recommended that all the reels be visually inspected at $25 X$ for pits, scratches, pin holes, etc. on the copper side first and then flyer side prior to dispositions. 
$-2-$

The other reels 2, 3, 7, and 8 can also be accepted based on plots 4, 5, 9, and 10 after discarding the 40 feet of the lead end of the roll which shows some unusual high copper thickness. The rest of the 210 feet of the reels indicate the thickness to be within $+/-10$ microinches.

Further Action: Please address the average copper thickness level of 173 microinches, which is a slight shift in the target from 170 microinches requirement, with the Design Agency, LANL for future Quality acceptance of raw material.

Also, it is suggested that we discuss with the vendor, Fort in Industries, Inc., the variation across the width of the roll for possible improvement in future shipment.

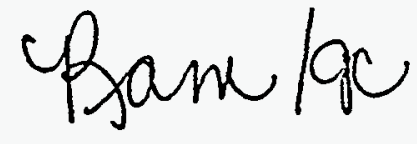

R. S. Ramachandra.

$\mathrm{RSR} / \mathrm{gc}$

Attachments

9 


\section{TABLE 1}

STATISTICAL DATA ON COPPER ON KAPTON

THICKNESS MEASUREMENT BY EDDY CURRENT

\begin{tabular}{|c|c|c|c|c|c|}
\hline ROLL-REEL\# & SAMPLE SIZE & $x$ & SIGMA & MIN & MAX \\
\hline $\begin{array}{l}2-2 \\
2-3 \\
2-4 \\
2-5 \\
2-6 \\
2-7 \\
2-8 \\
2-9\end{array}$ & $\begin{array}{l}43 \\
43 \\
40 \\
28 \\
43 \\
43 \\
43 \\
43\end{array}$ & $\begin{array}{l}169.4 \\
175.0 \\
175.2 \\
174.1 \\
171.7 \\
171.5 \\
171.3 \\
171.3\end{array}$ & $\begin{array}{l}2.69 \\
3.29 \\
2.97 \\
2.51 \\
2.07 \\
2.02 \\
2.28 \\
2.02\end{array}$ & $\begin{array}{l}165.1 \\
169.7 \\
167.4 \\
169.0 \\
168.8 \\
167.5 \\
168.3 \\
166.4\end{array}$ & $\begin{array}{l}175.1 \\
182.7 \\
182.4 \\
180.3 \\
177.6 \\
176.1 \\
174.5 \\
175.8\end{array}$ \\
\hline
\end{tabular}

326

$\begin{array}{lll}172.3 & 2.51 \quad 165.1\end{array}$

182.7

- The data is adjusted for the Eddy Current bias of -32 microinches

-33 data points after 210 feet of the roll \#2 considered as outliers, not included

-The overall average thickness of the roll \#2, including the outliers ( $n=359)$, is 172.8 microinches with a pooled standard deviation of 4.45 min. 


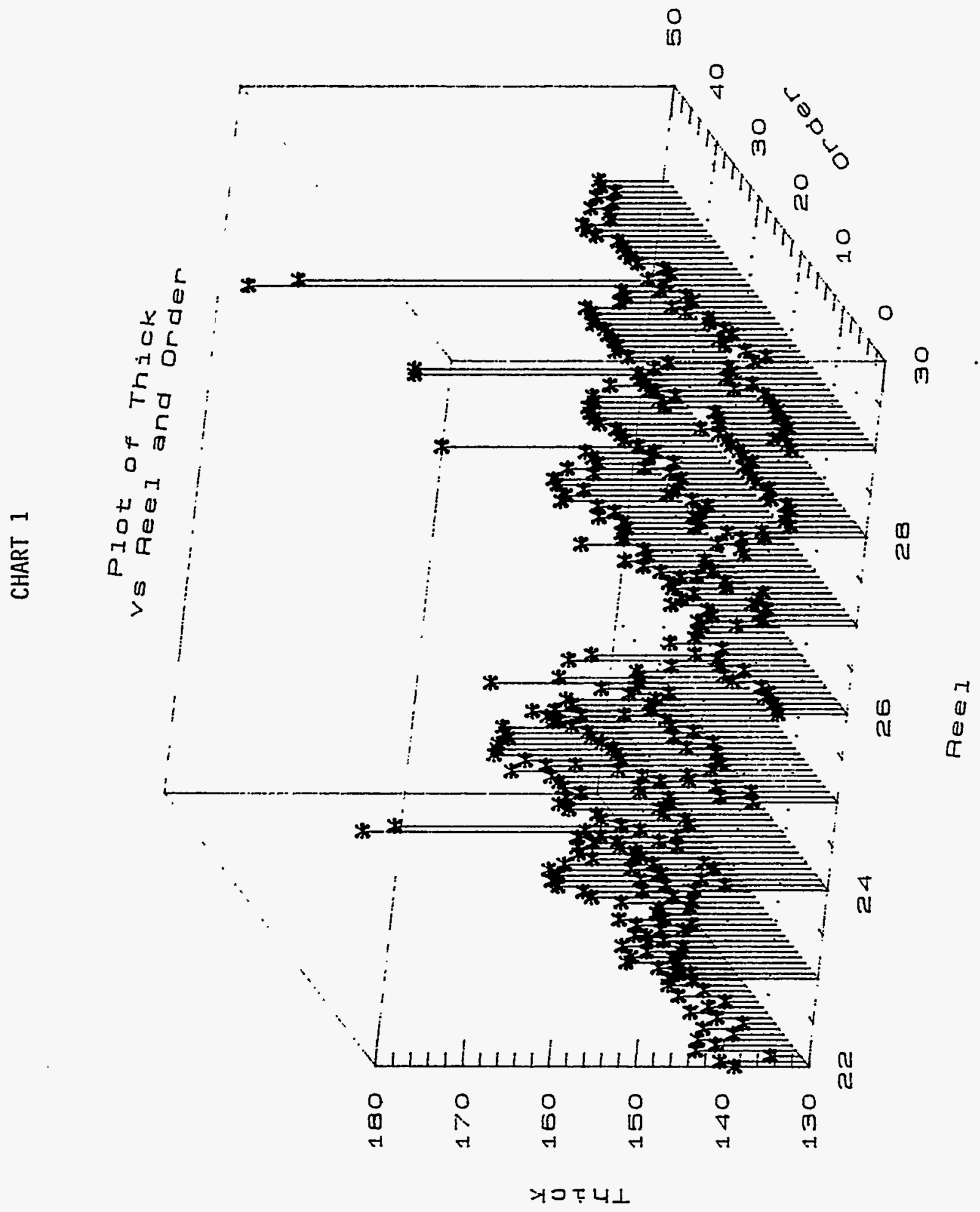




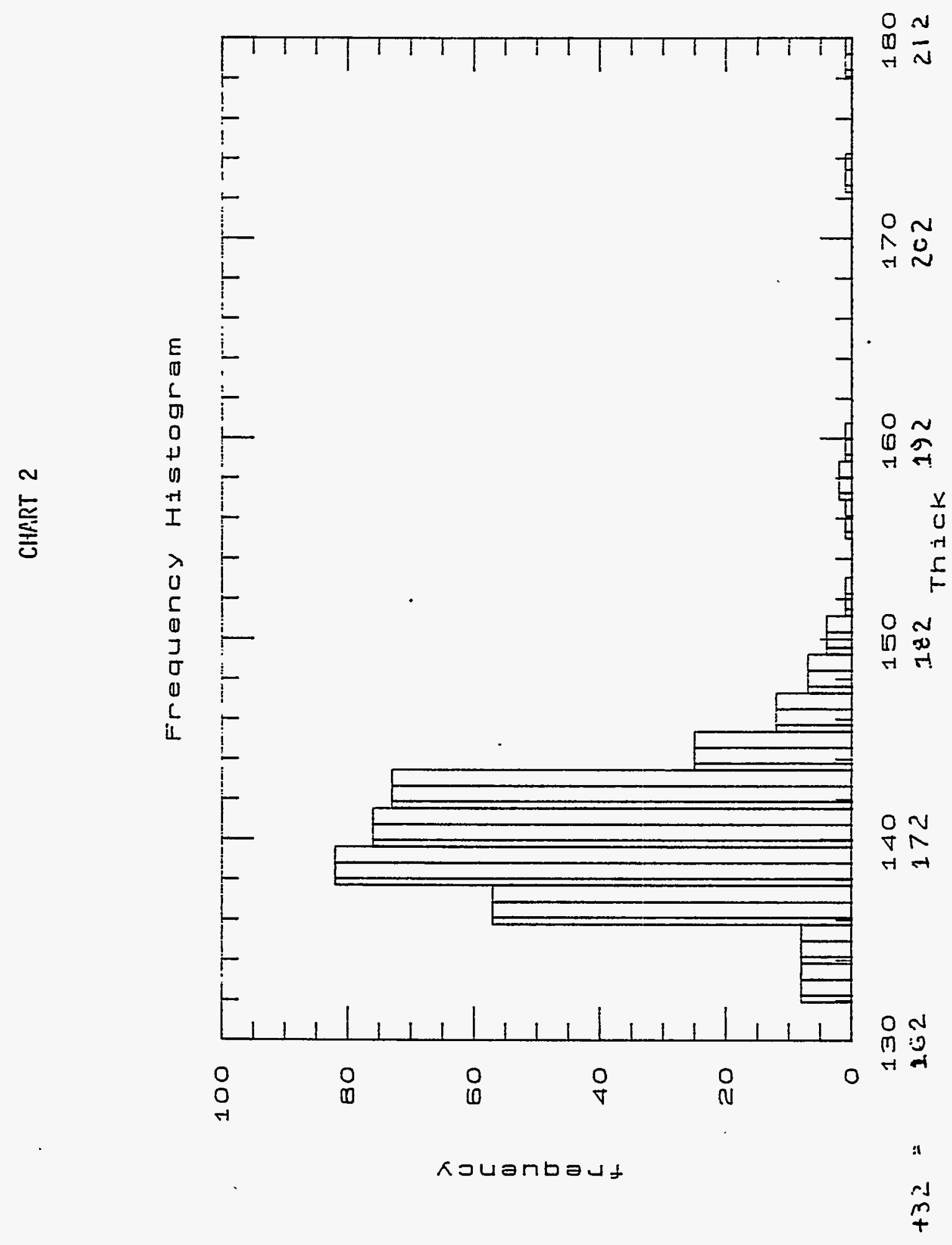




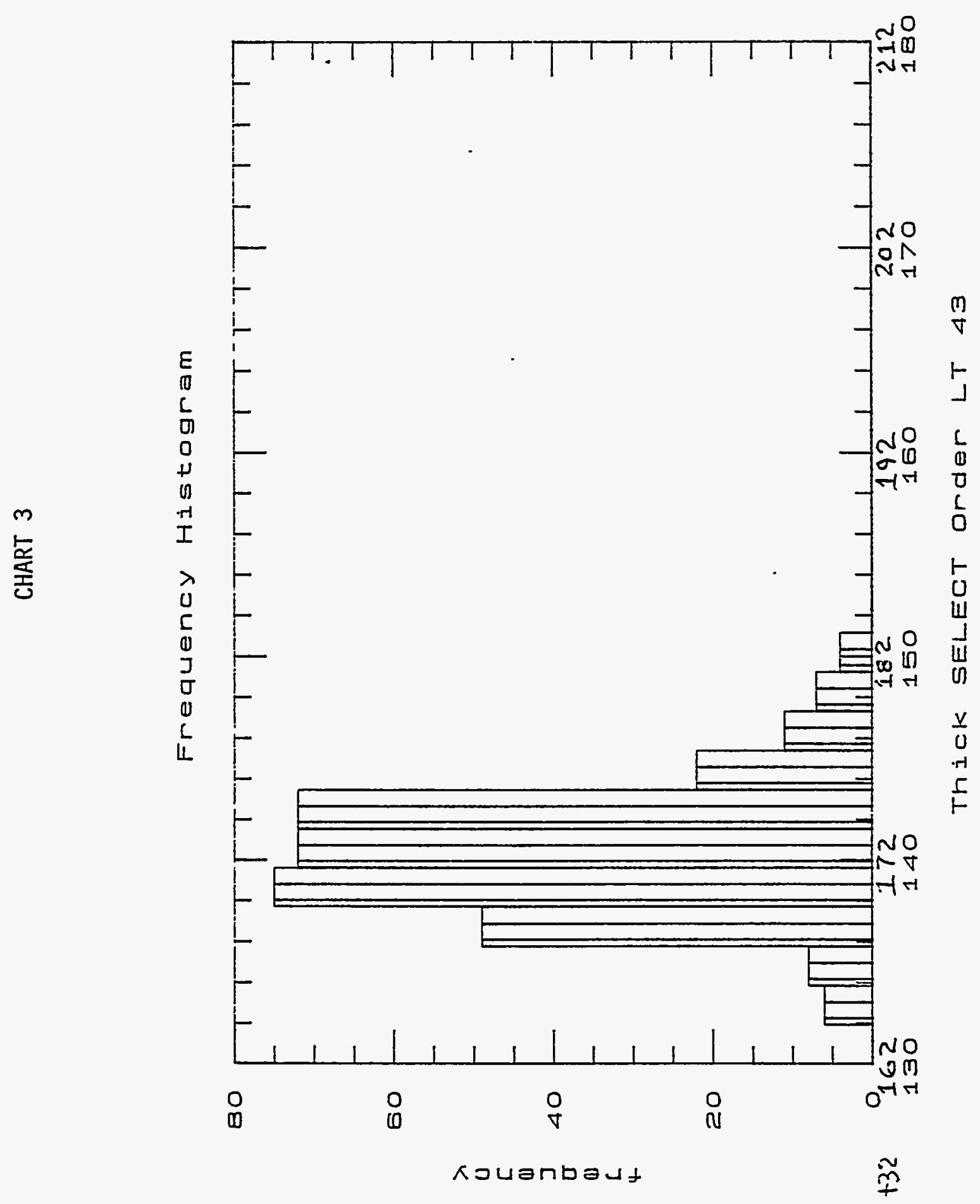



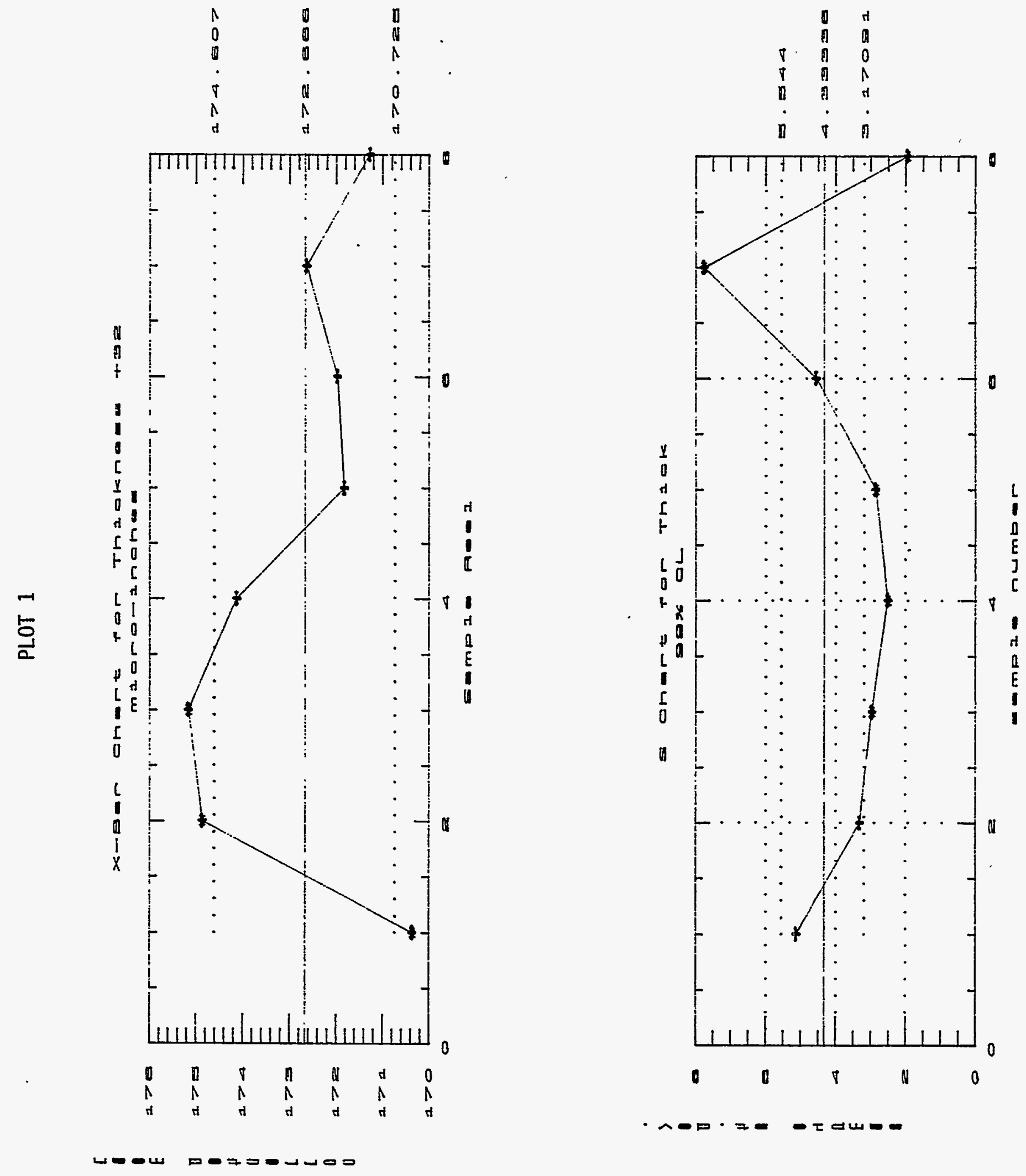


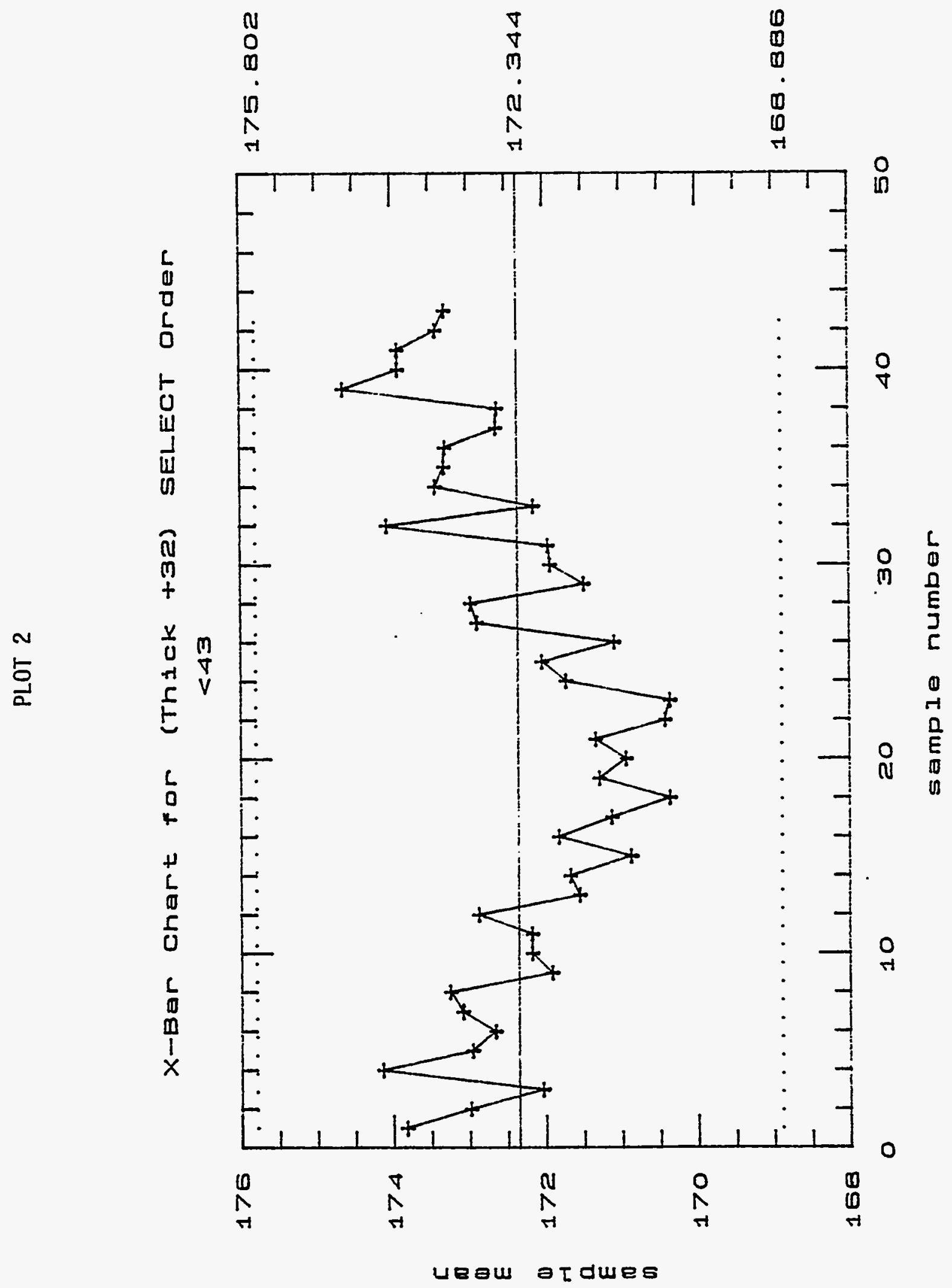




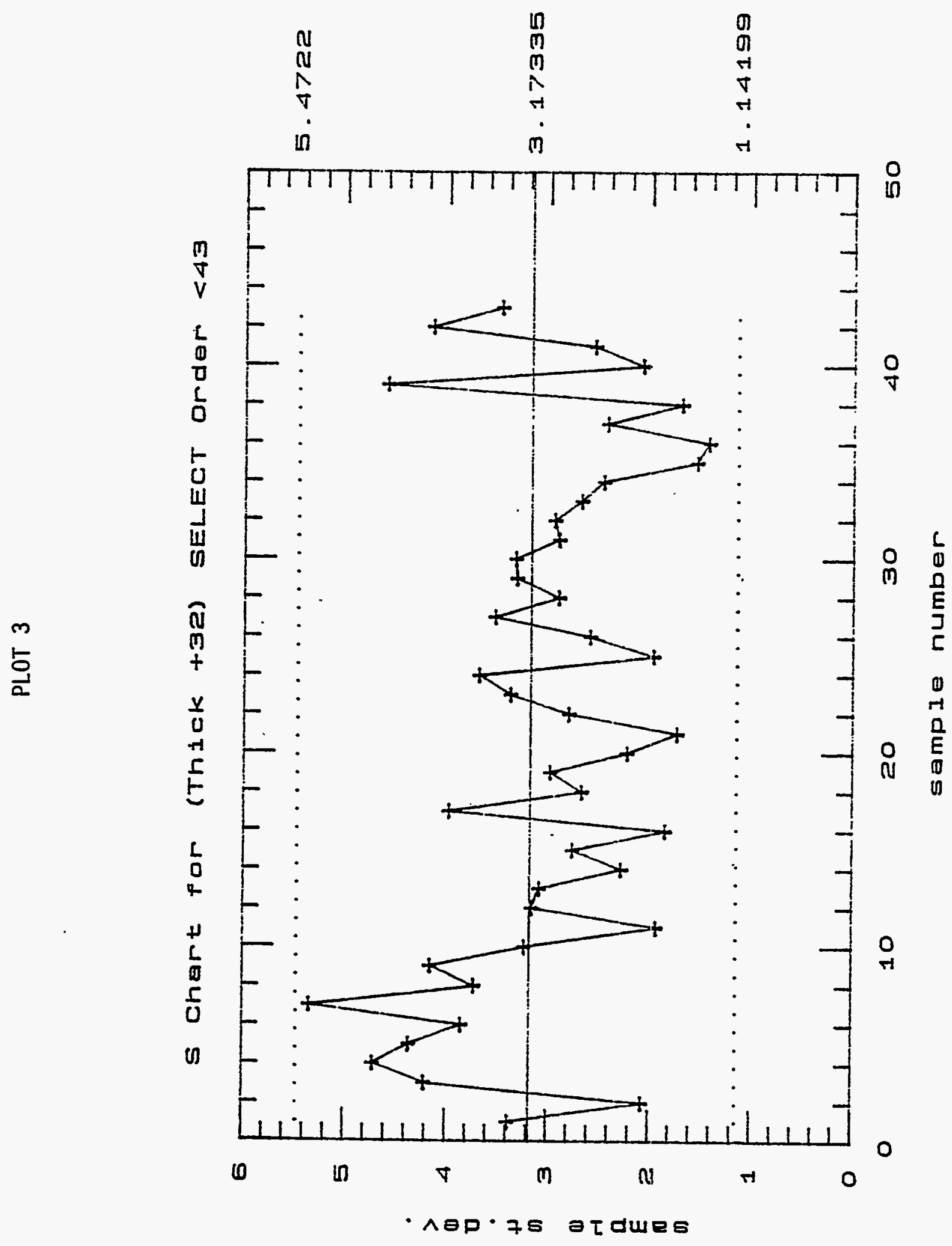




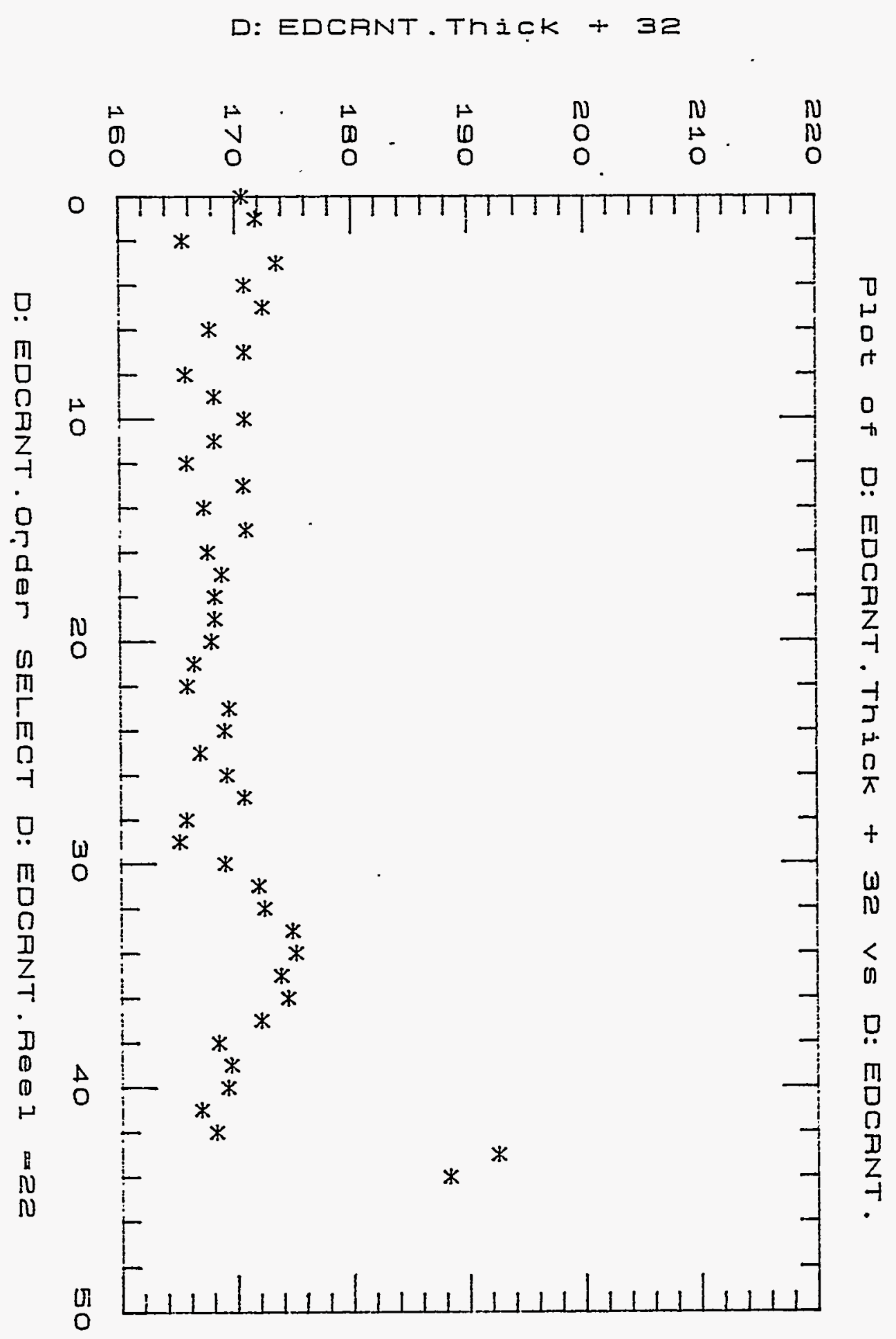


D: EDCRNT. Thick + 32.

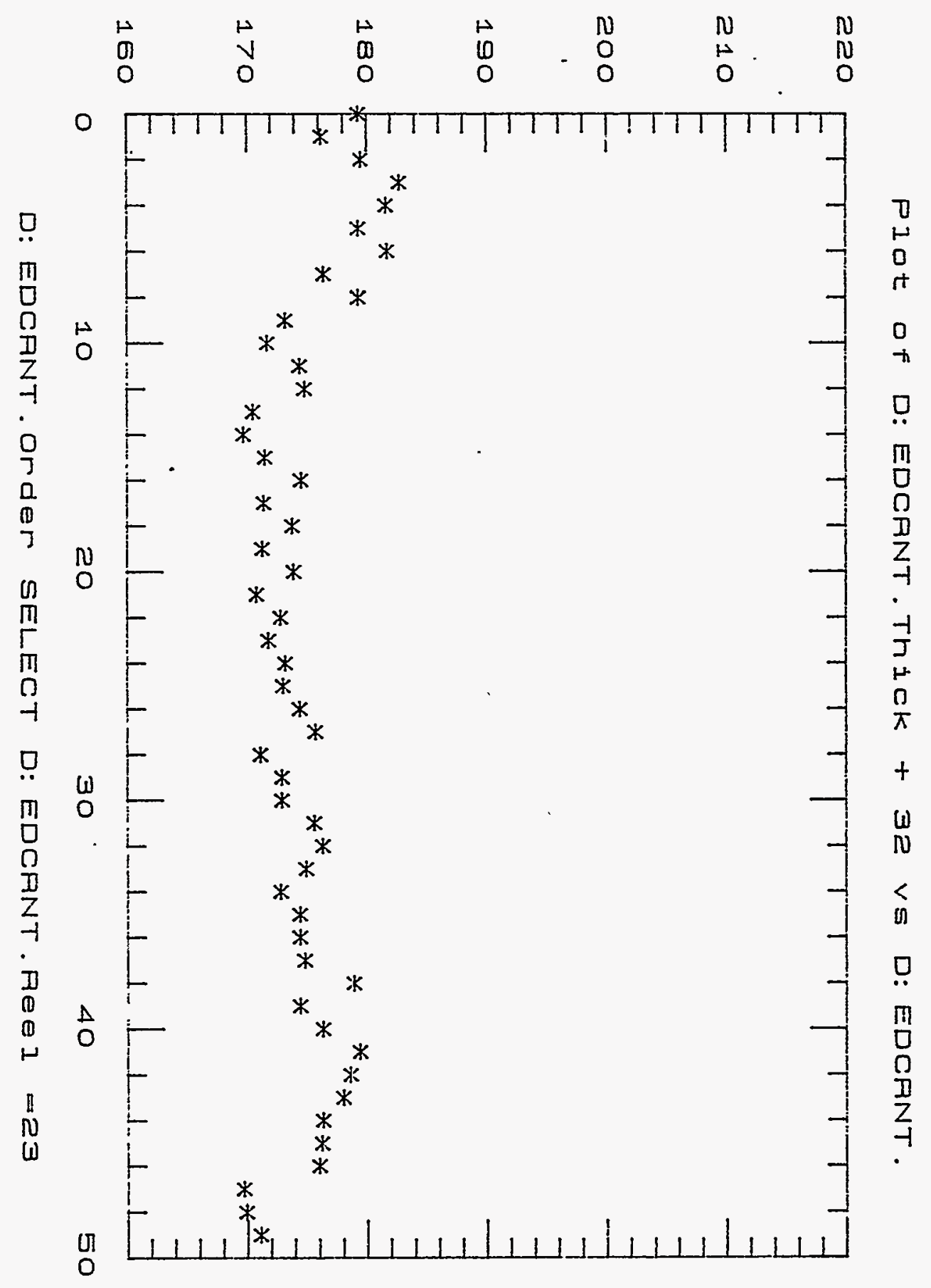

0
0
0 


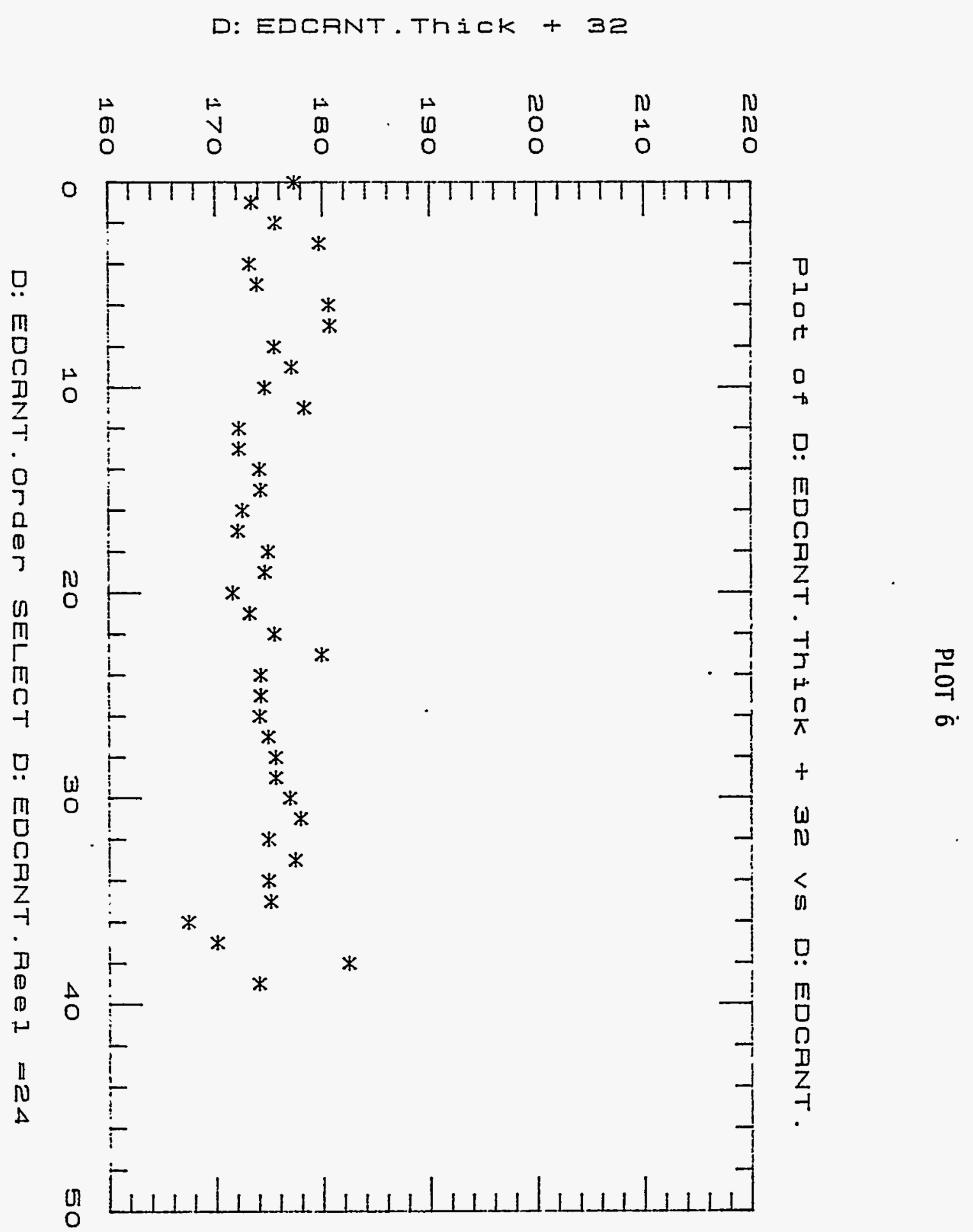


D: EDCRNT. ThiCK + 32

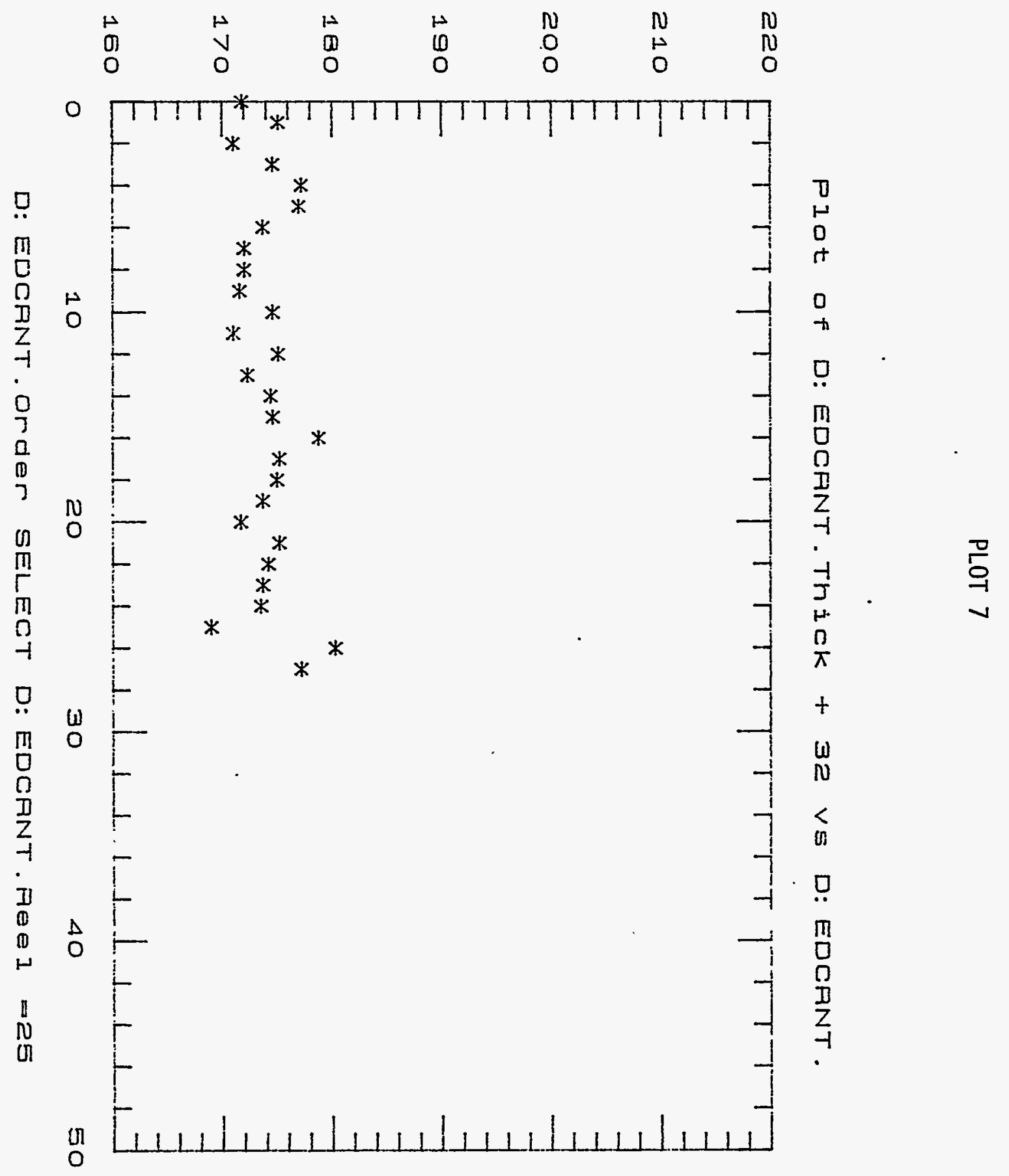




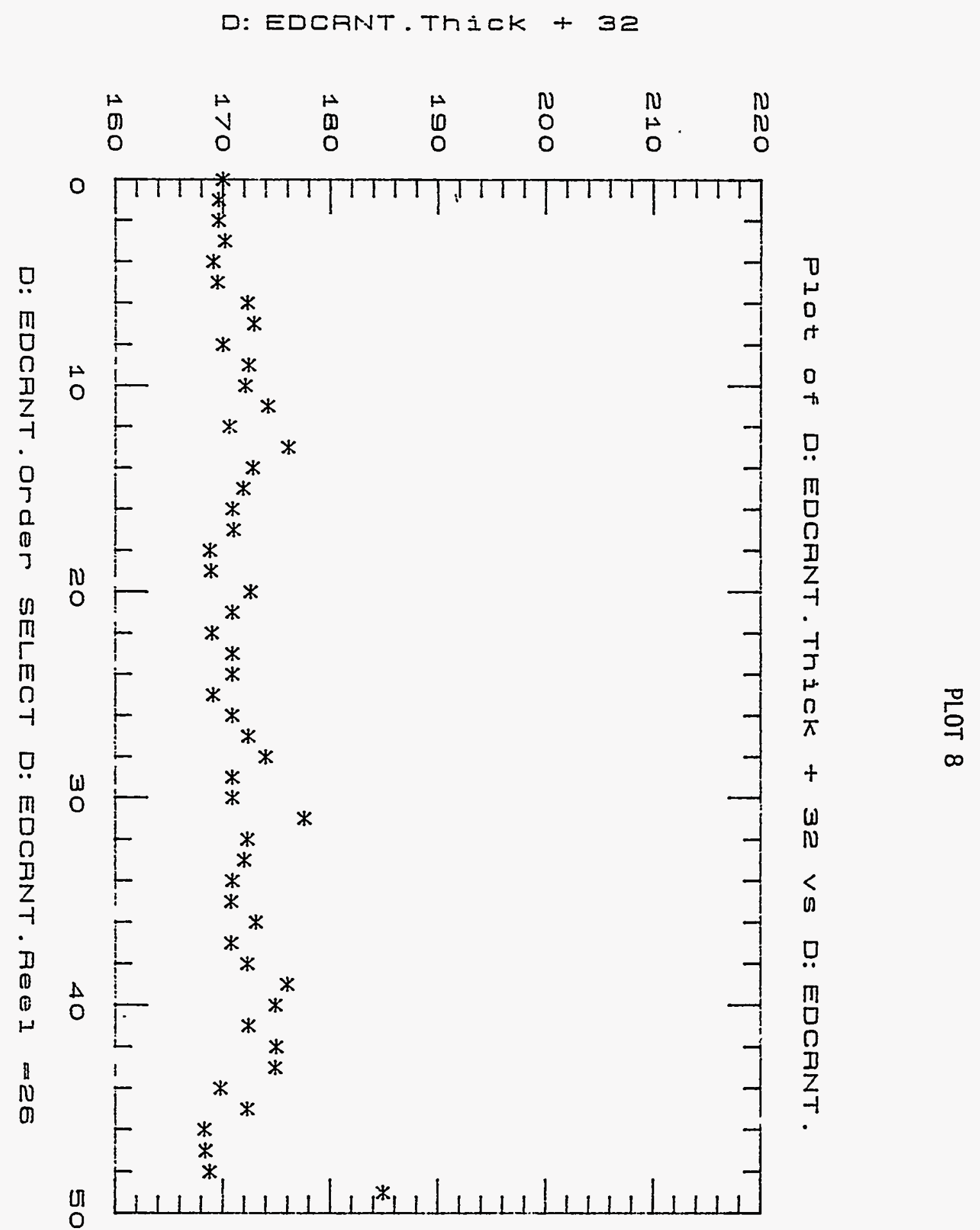


D: EDCRNT. ThiCK + 32

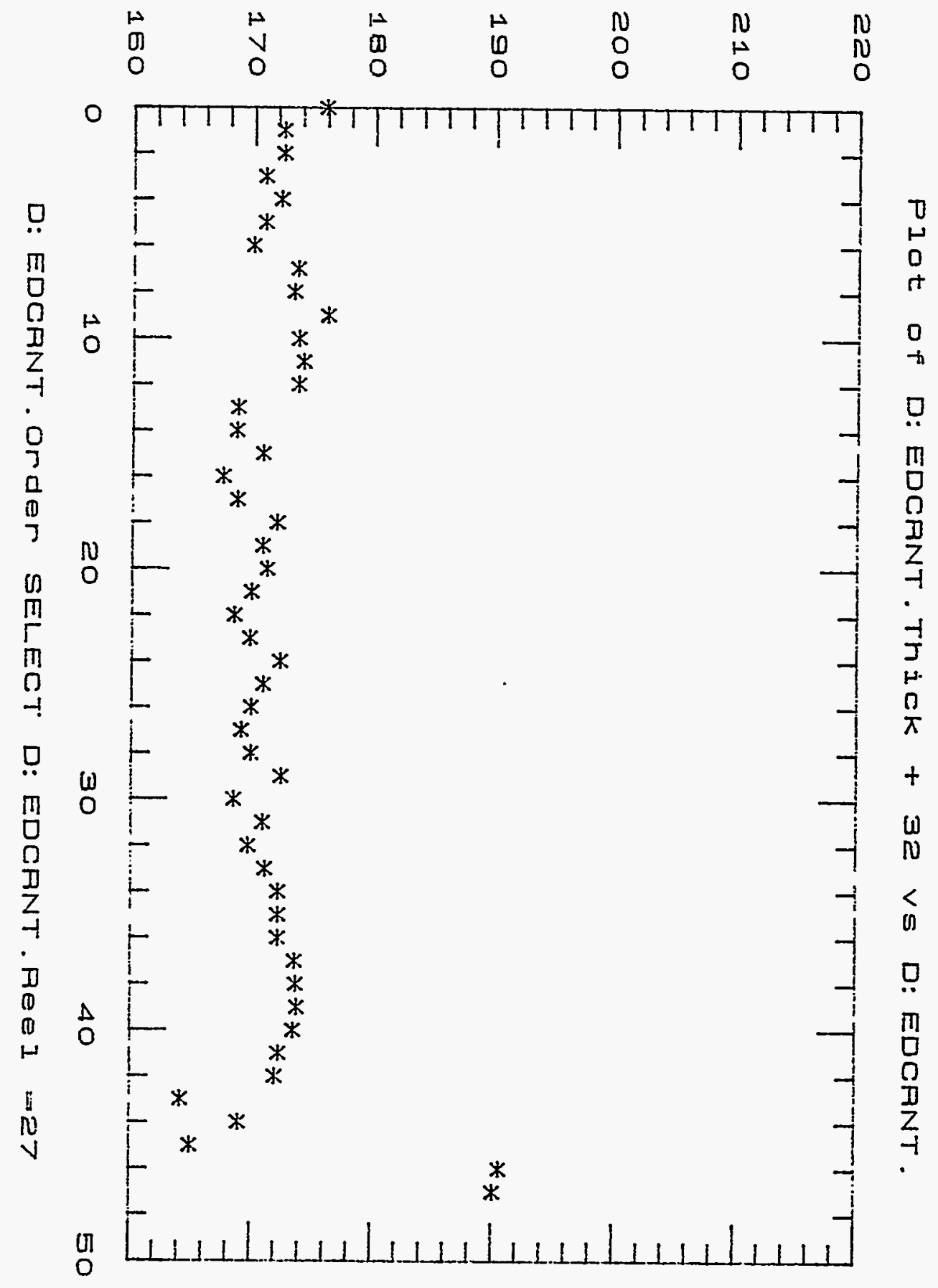




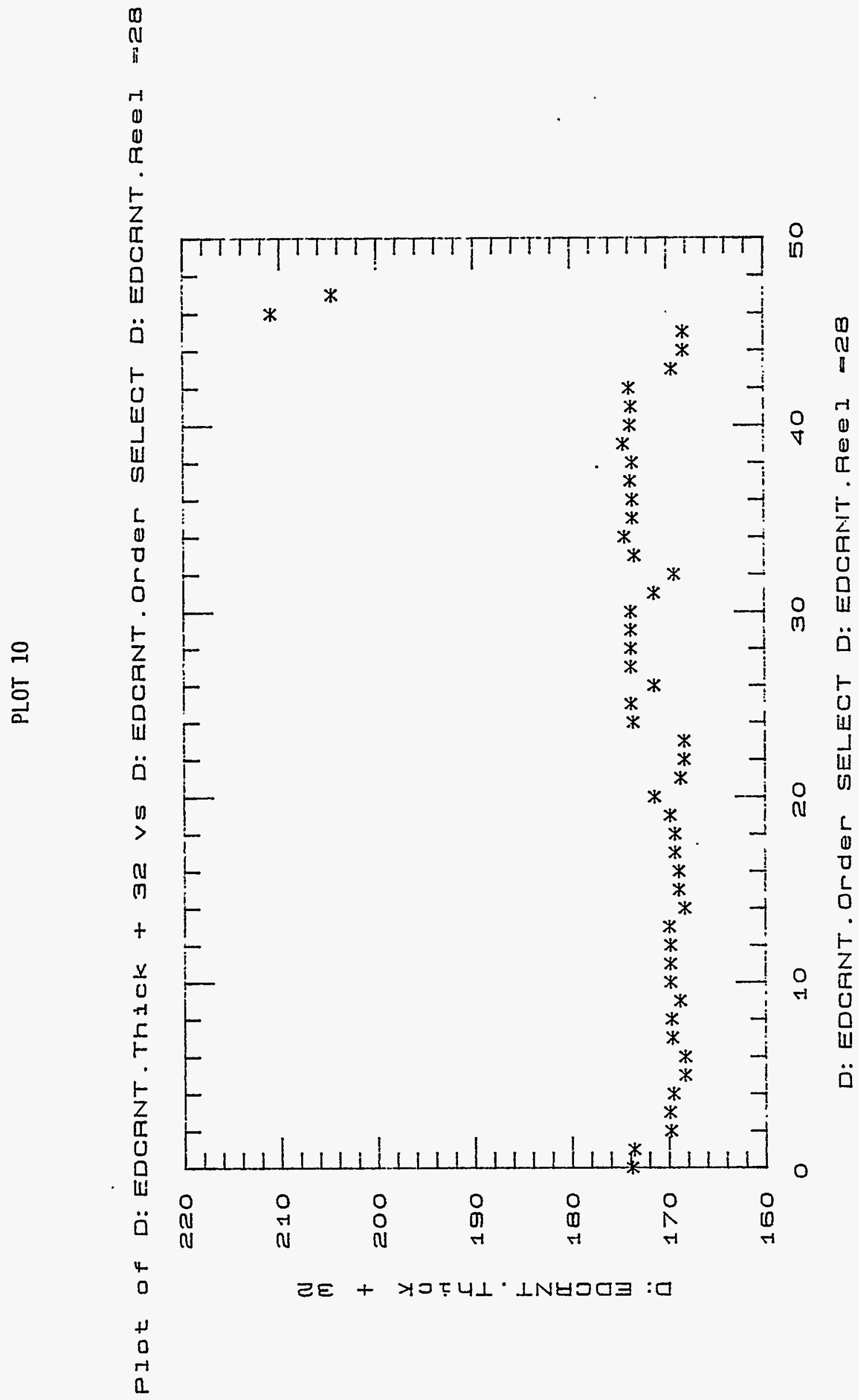




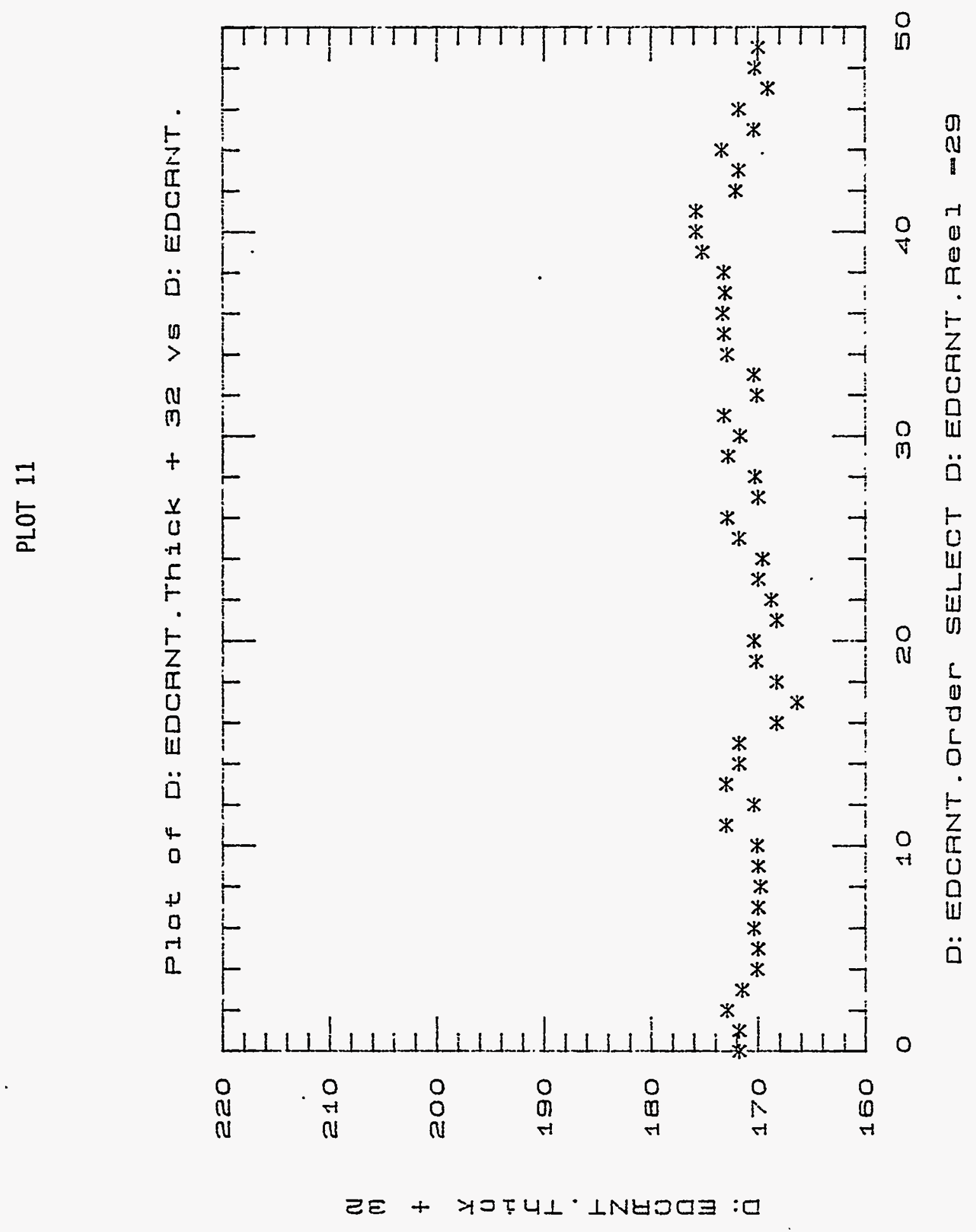




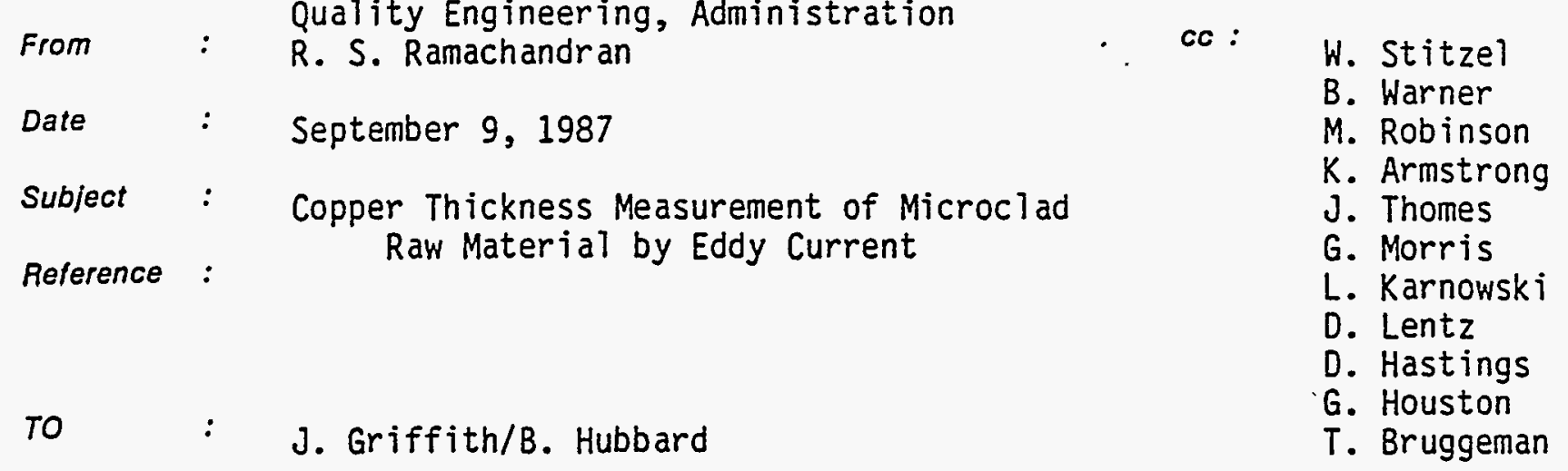

Microclad copper on kapton standards were selected to be used for Eddy Current calibration in measuring the thickness of $r$ aw material for making tape processed bridges. The copper thickness of reel \#1, MC3926, QC\# 37831 was measured by Eddy Current using two calibration standards: PVD standards and the new Microclad standards. Material Acceptance group performed these measurements.

In the past the PVD standards gave a bias of 32 microinches that had to be corrected. The new microclad standards should not have a bias and the data should not have to be corrected. The purpose of these measurements is to compare the data from the PVD standards to that of the new microclad standards.

The data in Table 1 showed only a difference of 12 microinches higher on the average with the microclad standards calibration vs. the expected bias of 32 microinches with the PVD standards. Chart \#1 shows that the reel thickness average is below the target of $175+/-12$ microinches tolerance. Chart $\# 2$ shows that the bias between the individual readings generated by PVD and Microclad standard calibration varies between +9 and -29.5 microinches.

A second reel is currently being measured by Eddy Current using both calibration techniques to obtain additional data. This reel will also be verified by $X-r a y$ Fluorescence to determine the true product value prior to incorporating the Microclad standard to eliminate the bias. The results of the second reel are not completed and will be summarized later.

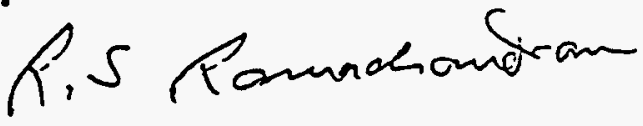

R. S. Ramachandran 


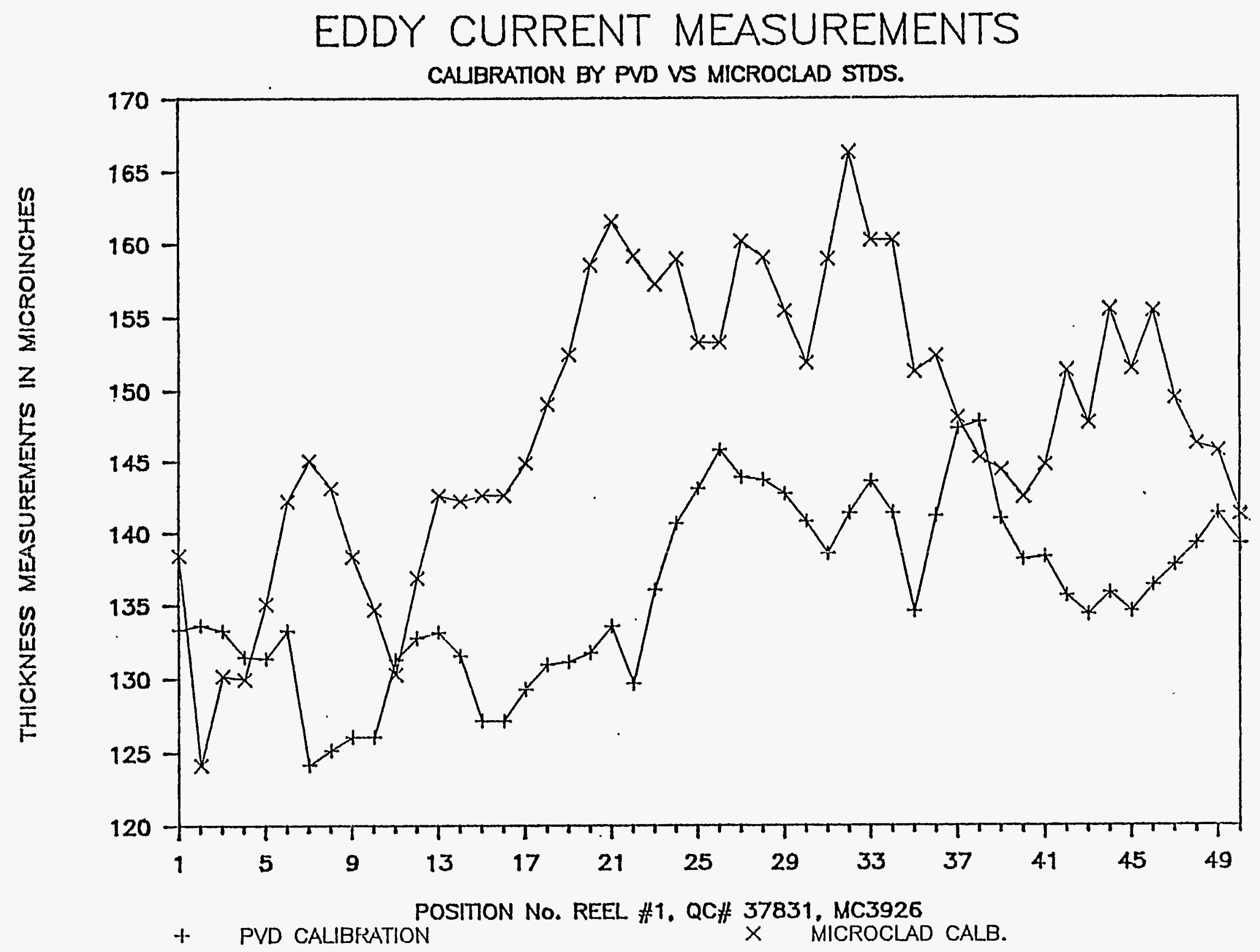


CHART 2

\section{EDDY CURRENT MEASUREMENTS}

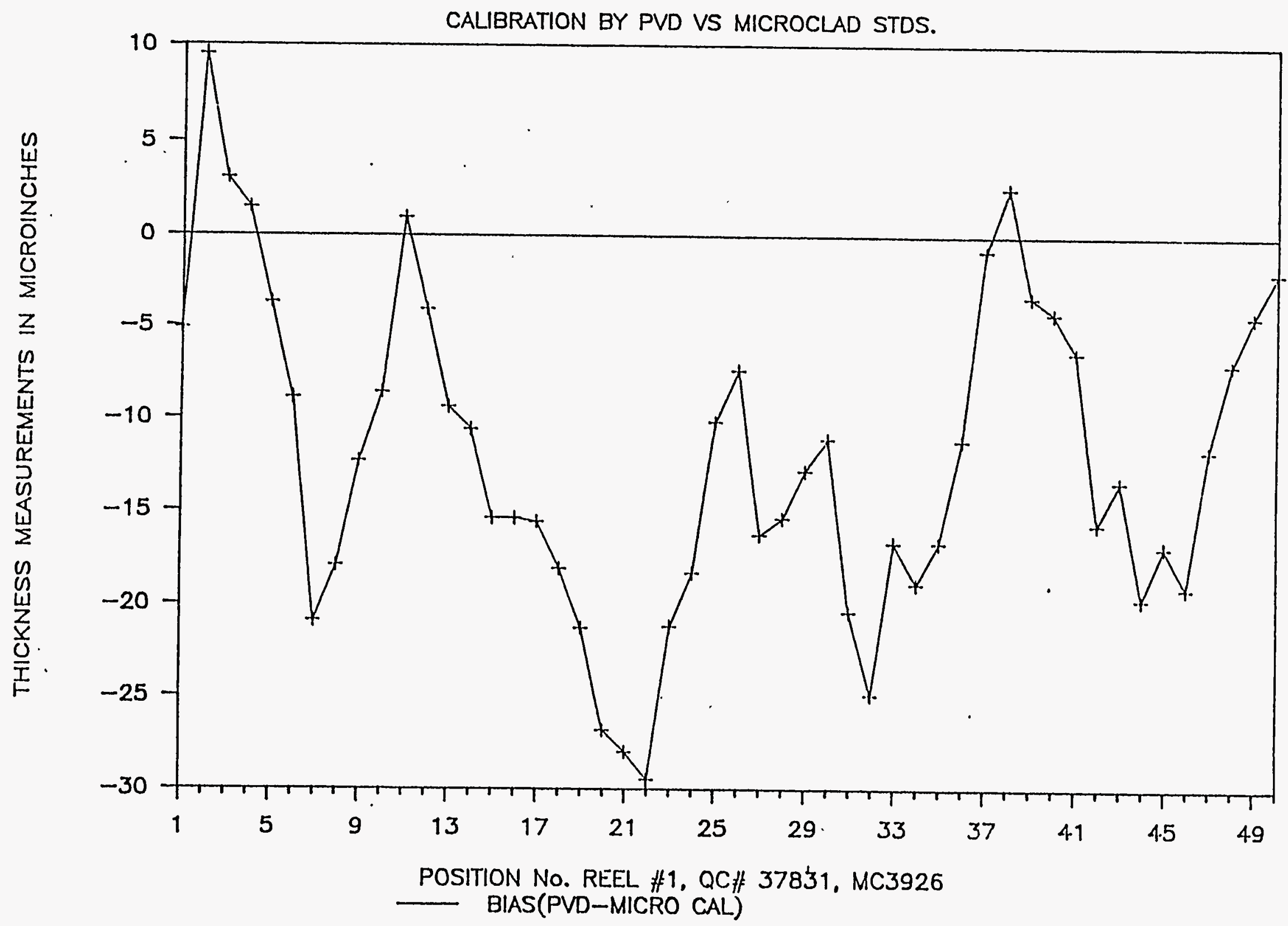




\section{Acknowledgments}

The authors would like to thank B. E. Hubbard and J. D. Hastings for their contribution to tape process development. The authors also extend special recognition to those Production, Quality, and Development personnel who contributed to the data collection and reduction. K. P. Armstrong claims no recognition for the research, only for the effort required to document it. 


\section{Glossary}

Artwork

Bridge

Bridge Length

Bridge Width

Eddy Current

Flyer

Kapton

LANL

Laseruler

LLNL

Microclad

Phototool

Radius Bridge

Reel

Receiving Inspection

Roll
See phototool.

Functioning copper foil portion of a slapper that drives the flyer.

Dimension of a bridge parallel to the electric current.

Dimension of a bridge perpendicular to the electric current.

Nondestructive technique for measuring substrate thickness; used to determine copper thickness on bridge (microclad) material.

Portion of a slapper detonator driven by rapid ionization of the bridge element (usually $0.001-i n$. to 0.002 -in. Kapton).

Trade name for a polyimide product produced by duPont.

Los Alamos National Laboratory.

Tool used to nondestructively measure substrate thickness; used to determine copper thickness on finished bridge circuits.

Lawrence Livermore National Laboratory.

Trade name of a copper-coated polyimide produced by Fortin Industries and used in fabricating bridges and flyers.

Tool used to create a circuit image. A phototool contains the image of the desired circuit and exposes the image onto a chemically conditioned surface.

Bridge for which the length is defined by a radius such that the center of the bridge is in the thinnest region.

Sample of material slit to a width of $35 \mathrm{~mm}$ and wound around a core.

Area at Mound where incoming material is inspected for conformance to specifications.

Sample of material as purchased from a vendor. A roll is the original width, usually 12 in. A roll is later slit to thinner widths to become reels. 
SNLA

Square Bridge

Tape Process

Vidicom

Wet Processing
Sandia National Laboratories, Albuquerque.

Bridge for which the width is uniform from end to end.

Method of producing flexible circuits in a reel-to-reel fashion. This process is unique to Mound.

Vision system produced by Vidicom to inspect bridge length and width.

Process of laminating, exposing, developing, etching, and stripping a flexible circuit image. 


\section{Distribution}

\section{External}

S. G. Barnhart, Sandia National Laboratories, Albuquerque

G. E. Dahms, Sandia National Laboratories, Albuquerque

R. McCormick, Los Alamos National Laboratory

J. A. Morley, DOE/DAO

\section{Internal}

K. P. Armstrong

J. R. Brinkman

T. M. Bruggeman

T. A. Demana

R. A. Fischbein

M. P. Fisher

E. D. Freese

E. D. Hill

G. L. Houston

M. A. Huelskamp

C. W. Huntington

D. P. Kelly

D. E. Michel

G. L. Morris

R. S. Ramachandran

M. D. Stoltz

J. A. Thomes

R. E. Vallee

S. I. Waskey

W. Yurkowsky, Jr.

Library (10)

Publications 


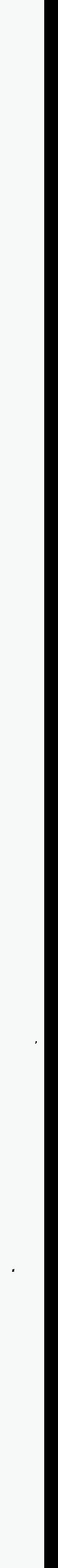

